\title{
Economic Integration and Political Disintegration
}

\section{Citation}

Alesina, Alberto, Enrico Spolaore, and Romain Wacziarg. 2000. Economic integration and political disintegration. American Economic Review 90(5): 1276-1296.

\section{Published Version}

http://www.jstor.org/stable/2677851

\section{Permanent link}

http://nrs.harvard.edu/urn-3:HUL.InstRepos:4553029

\section{Terms of Use}

This article was downloaded from Harvard University's DASH repository, and is made available under the terms and conditions applicable to Other Posted Material, as set forth at http:// nrs.harvard.edu/urn-3:HUL.InstRepos:dash.current.terms-of-use\#LAA

\section{Share Your Story}

The Harvard community has made this article openly available.

Please share how this access benefits you. Submit a story.

\section{Accessibility}


NBER WORKING PAPER SERIES

\title{
ECONOMIC INTEGRATION AND \\ POLITICAL DISINTEGRATION
}

\author{
Alberto Alesina \\ Enrico Spolaore \\ Romain Wacziarg
}

\author{
Working Paper 6163 \\ http://www.nber.org/papers/w6163
}

\author{
NATIONAL BUREAU OF ECONOMIC RESEARCH \\ 1050 Massachusetts Avenue \\ Cambridge, MA 02138 \\ September 1997
}

We thank Francesco Caselli, Jeffrey Frieden, David Laibson, Ronald Rogowski, Fabio Schiantarelli, Jeffrey Williamson and seminar participants at Harvard University, Tulane University and the London School of Economics for useful suggestions. We also thank Teng Chamchumrus for excellent research assistance. This research is supported by an NSF grant to the NBER. This paper is part of NBER's research programs in Economic Fluctuations and Growth, International Finance and Macroeconomics, and International Trade and Investment. Any opinions expressed are those of the authors and not those of the National Bureau of Economic Research.

(C) 1997 by Alberto Alesina, Enrico Spolaore and Romain Wacziarg. All rights reserved. Short sections of text, not to exceed two paragraphs, may be quoted without explicit permission provided that full credit, including $\mathbb{C}$ notice, is given to the source. 
Economic Integration and Political Disintegration

Alberto Alesina, Enrico Spolaore

and Romain Wacziarg

NBER Working Paper No. 6163

September 1997

JEL Nos. F15, F43

Economic Fluctuations and Growth, International Finance and Macroeconomics and International Trade and Investment

\begin{abstract}
Trade liberalization and political separatism go hand in hand. In a world of trade restrictions, large countries enjoy economic benefits because political boundaries determine the size of the market. In a world of free trade and global markets even relatively small cultural, linguistic or ethnic groups can benefit from forming small and homogeneous political jurisdictions that trade peacefully and are economically integrated with others. This paper provides a formal model of the relationship between openness and the equilibrium number and size of countries, and successfully tests two implications of the model. The first one is that the economic benefits of country size depend on and are mediated by the degree of openness to trade. The second is that the history of Nation-State creations and secessions is influenced by the trade regime.
\end{abstract}
Alberto Alesina
Enrico Spolaore
Department of Economics
Department of Economics
Romain Wacziarg
Harvard University
The Ohio State University
Department of Economics
Cambridge, MA 02138
Columbus, $\mathrm{OH} 43210$
Harvard University
Cambridge, MA 02138
and NBER
aalesina@harvard.edu 


\begin{abstract}
"In a regime of Free Trade and free economic intercourse it would be of little consequence that iron lay on one side of a political frontier, and labor, coal, and blast furnaces on the other. But as it is, men have devised ways to impoverish themselves and one another; and prefer collective animosities to individual happiness." John Maynard Keynes, The Economic Consequences of the Peace, p. 99.
\end{abstract}

\title{
1 Introduction
}

The number of countries in the world increased from 74 in 1946 to 192 in 1995. In 1995, 87 countries had less than 5 million inhabitants, 58 less than 2.5 million and 35 less than 500,000. More than half of the world's countries are smaller (in population) than the State of Massachusetts. ${ }^{1}$ In the same half century, the volume of imports plus exports as a share of world GDP, in a sample of 61 countries, has increased by roughly $40 \%$.

Figure I displays a strong positive correlation, from 1870 to today, between the number of countries in the world and a measure of trade openness, the average ratio of imports plus exports to GDP in a group of nine countries $^{2}$. Similarly, Figure II shows an inverse relationship between average tariff rates on manufactured products and the number of countries, in a selected group of countries for which tariff data were available. Tariff rates were slowly increasing between 1870 and the 1920 s, while the number of countries was stable or slowly decreasing. After the Second World War tariff rates fell dramatically and the number of countries increased rapidly.

This paper argues that trade openness and political separatism go hand in hand: economic integration leads to political "disintegration".

We build upon a very simple idea. Consider a model where the size of the market influences productivity. In a world of trade restrictions, the

\footnotetext{
${ }^{1}$ In 1990 Massachusetts had a population of $6,016,425.98$ countries have smaller populations.

${ }^{2}$ These countries are France, Britain, Denmark, Italy, Norway, Portugal, Australia, Brazil and Sweden, the only countries for which reliable trade data were available continuously since 1870 . These countries are representative of trends that affected world trade volumes, however, as the correlation between their average trade to GDP ratio since 1950 and that of a much wider sample of 61 countries since 1950 is 0.93 .
} 
political boundaries of a country influence the size of the country's market, and therefore its productivity level. On the contrary, with free trade the size of countries is irrelevant for the size of markets, so the size of a country is unrelated to its productivity. ${ }^{3}$ It follows that the equilibrium number of countries and the extent of economic integration are interdependent.

More specifically, this paper pursues two goais: Firstly, we develop an explicit model of geography and trade which endogenously derives the equilibrium number and size of countries as a function of the trade regime. Secondly, we provide empirical evidence for two critical implications of the model: i) the effect of country size on economic growth should be mediated by the degree of openness; ii) the long term history of country formation and separation has been influenced by the pattern of trade openness and economic integration and vice versa. In particular, we emphasize a tradeoff between the economic benefits of size, which are a function of the trade regime, and the costs of heterogeneity resulting from large and diverse populations.

On the theory side, this paper links the literature on geography and trade with a recent formal literature on country formation, and, in particular, the paper by Alesina and Spolaore (1997). ${ }^{4}$ It also relates to the analysis of economic integration and preferential trade agreements, but unlike the traditional analysis of trade blocs, we focus on the endogenous formation of sovereign jurisdictions. ${ }^{5}$ Empirically, our paper is related to the recent literature on the effects of openness on economic growth, such as Ades and Glaeser (1994), Sachs and Warner (1995) and Wacziarg (1997), and the effects of openness on public policy, such as Rodrik (1996) and Alesina and Wacziarg, (1997).

The organization of this paper is as follows: Section 2 presents the model linking country size to productivity. Section 3 provides cross-country evidence on how the interaction between country size and the degree of trade

\footnotetext{
${ }^{3}$ These ideas are discussed informally by historians of nation building, such as Hobsbawm (1990), are tested by Ades and Glaeser (1994) and are modeled in a stylized fashion by Alesina and Spolaore (1997), Spolaore (1995) and Mansori (1996). Wittman (1991) also mentions this point.

${ }^{4}$ For a recent survey of this literature, see Bolton, Roland and Spolaore (1996).

${ }^{5}$ The classical reference is Viner (1950). More recent contributions to this large literature include Krugman (1991a, 1991b) and the papers in the volumes edited by De Melo and Panagariya (1993) and Frenkel (1997).
} 
liberalization influences economic growth. Section 4 derives endogenously the equilibrium number of countries as a function, among other things, of the trade regime. Section 5 discusses, with a brief historical excursion, the relationship between country formation and trade regimes throughout the past two centuries. The last section concludes.

\section{The Model: Country Size and Production:}

\subsection{Assumptions and description of the model}

The world is composed of $W$ "economic units" (in short "units"), which are the basic entities carrying out economic activities. These units are not geographically mobile. They can be interpreted as homogeneous regions, themselves composed of one or more identical and geographically immobile individuals. A "country" $k$ is made of $S_{k}$ units, where $1 \leq S_{k} \leq W$. A country is identified by borders which separate members of country $k$ from those of country $k^{\prime}$.

A unique final good, $Y$, is produced and consumed in each unit $i$ with the following production function:

$$
Y_{i}=A_{i}\left(\sum_{j=1}^{n} X_{j i}^{\alpha}\right) L_{i}^{1-\alpha}
$$

with $0<\alpha<1$. In equation (1), $X_{i j}$ denotes the amount of intermediate input $j$ used in unit $i$ and $L_{i}$ is unit $i$ 's labor, which is supplied inelastically. There is no labor mobility across units. We assume that $n=W$, which implies that every unit can use the intermediate inputs produced by all other units in order to produce the final good. The markets for final goods and labor inputs are perfectly competitive.

Each unit produces one and only one intermediate input $\left(X_{i}\right.$ for unit $i$ ) using a unit specific stock of an inexhaustible natural resource. In the static version of our model, we assume that this stock yields $K_{i}$ units of the intermediate good. In the dynamic version, we assume that the unit-specific 
intermediate good can be accumulated like capital, so that resources must be diverted away from consumption to finance any increase in the stock of $K_{i}$. Intermediate goods are sold in a competitive market within the unit. They can also be sold to other units, in which case one incurs costs associated with trade. We model these costs with a standard "iceberg" assumption:

Barriers to Trade: When $Z$ units of an intermediate good are shipped from unit $i^{\prime}$ to unit $i^{\prime \prime}$, only $q\left(i^{\prime}, i^{\prime \prime}\right) Z$ arrive, with $0<q\left(i^{\prime}, i^{\prime \prime}\right)<1$ for any $i^{\prime}, i^{\prime \prime}$ units with $i^{\prime} \neq i^{\prime \prime}$.

The parameter $q($.$) is a function of all the obstacles which make inter-$ unit trade costly. These obstacles can be geographical, technological or political. Generally, costs associated with exchange across political borders arise because trade takes place between different political and legal systems. A simple and useful specification of $q($.$) is the following:$

$$
q\left(i^{\prime}, i^{\prime \prime}\right)=\left(1-\beta_{i^{\prime} i^{\prime \prime}}\right)\left(1-\delta_{i^{\prime} i^{\prime \prime}}\right)
$$

where $0 \leq \beta_{i^{\prime} i^{\prime \prime}} \leq 1$ and $0 \leq \delta_{i^{\prime} i^{\prime \prime}} \leq 1$. The parameter $\beta_{i^{\prime} i^{\prime \prime}}$ measures political trade barriers between $i^{\prime}$ and $i^{\prime \prime}$, while $\delta_{i^{\prime} i^{\prime \prime}}$ measures physical barriers. ${ }^{6}$

\subsection{Solution of the static model}

In order to obtain a closed form solution for the model, we make the following simplifying assumptions:

A1. $A_{i}=A ; K_{i}=K ; L_{i}=1$ for $i=1,2, \ldots W$.

A2. $\delta_{i^{\prime} i^{\prime \prime}}=0$ for every $i^{\prime}, i^{\prime \prime}$

A3. Policy induced trade barriers are zero for units belonging to the same country and constant for international trade. More formally:

\footnotetext{
${ }^{6}$ Note that certain policy induced trade barriers, for example tariffs, generate fiscal revenues. We are assuming that these revenues do not influence the volume of production. This would not be the case, for instance, in a model where productive public goods were used in production.
} 


$$
\begin{aligned}
& \beta_{i^{\prime} i^{\prime \prime}}=0 \text { if } i^{\prime} \text { and } i^{\prime \prime} \text { belong to the same country } \\
& \beta_{i^{\prime} i^{\prime \prime}}=\beta \text { otherwise }
\end{aligned}
$$

The first two assumptions impose symmetry in the model. ${ }^{7}$ Although they considerably simplify the algebra, they should not affect the qualitative nature of our results. $\Lambda 2$ is relaxed in the Appendix, with no important changes. Assumption $A 3$ is, in a sense, the definition of a country in our model: unlike exchange within countries, trade across borders entails some costs.

In the static version of the model, maximizing utility is equivalent to maximizing production, i.e. consumption. The solution of the model is as follows (more details can be found in the Appendix):

i. Define: $\theta \equiv(1-\beta)^{\frac{\alpha}{1-\alpha}}$. The amount of intermediate good that unit $i$ ships to another unit belonging to the same country, $Z_{i}^{d}$, (where the superscript $d$ stands for domestic and $S_{i}$ refers to the number of units in unit $i$ 's country) is:

$$
Z_{i}^{d}=\frac{K}{S_{i}+\theta\left(W-S_{i}\right)}
$$

ii. The amount of intermediate good that unit $i$ ships to another unit not belonging to the same country, $Z_{i}^{f}$, (where the superscript $f$ stands for foreign) is given by:

$$
Z_{i}^{f}=\frac{\theta K}{S_{i}+\theta\left(W-S_{i}\right)}
$$

iii. Each unit's final output is:

$$
Y_{i}=A S_{i}\left(\frac{K}{S_{i}(1-\theta)+\theta W}\right)^{\alpha}+A \sum S_{j} \theta\left(\frac{K}{S_{j}(1-\theta)+\theta W}\right)^{\alpha}
$$

\footnotetext{
${ }^{7}$ A1 implicitly assumes that capital cannot be accumulated, which means that our model can be solved separately for each period, i.e. we are solving a static model. The dynamic version of the model is developed below.
} 
where the summation is over countries other than unit $i$ 's. Note that the parameter $\theta$, which is inversely related to the level of international barriers $\beta$, represents the degree of openness in each country: if $\theta=0$, all trade is domestic, while if $\theta=1$, each unit will export the same amount of the intermediate good to each other unit, irrespective of whether they belong to the same country or not.

The difference between the incomes of two units $i^{\prime}$ and $i^{\prime \prime}$, belonging to different countries of size $S_{i^{\prime}}$ and $S_{i^{\prime \prime}}$ respectively, can be written as follows:

$$
Y_{i^{\prime}}-Y_{i^{\prime \prime}}=A K^{\alpha}\left[\frac{(1-\theta) S_{i^{\prime}}}{\left((1-\theta) S_{i^{\prime}}+\theta W\right)^{\alpha}}-\frac{(1-\theta) S_{i^{\prime \prime}}}{\left((1-\theta) S_{i^{\prime \prime}}+\theta W\right)^{\alpha}}\right]
$$

Equation (7) implies the following results:

a). When $\theta=1$ (complete openness), each region has the same income independently of the size of its country: $Y_{i^{\prime}}=Y_{i^{\prime \prime}}$. In this case, country size imposes no constraint on the level of income within each country.

b). When $\theta<1$, larger countries have larger incomes and the difference $\left|Y_{i^{\prime}}-Y_{i^{\prime \prime}}\right|$, for $S_{i^{\prime}} \neq S_{i^{\prime \prime}}$, is decreasing in $\theta$. This means that, at higher levels of openness, country size imposes less of a constraint on income; equivalently, larger countries experience lower gains from increased openness than smaller countries:

$$
\frac{d\left|Y_{i^{\prime}}-Y_{i^{\prime \prime}}\right|}{d \theta}<0
$$

In order to illustrate these results more clearly, we now examine the case of equal country sizes. When all countries have equal size $S$, equation (6) simplifies as follows:

$$
Y=A[S+(W-S) \theta]^{1-\alpha} K^{\alpha}
$$


In equation (9), $S$ denotes country size, and $(W-S)$ is the size of the "rest of the world". Inspection of equation (9) reveals the following result:

Proposition 1. The amount of production of the final good, $Y$, is increasing in openness $\theta$ (for a given country size), increasing in country size $S$ (for a given level of openness), and decreasing in size of countries multiplied by openness, $S \theta$.

\subsection{The dynamic framework.}

We now extend the model to a dynamic setting in which we relate economic growth to country size and openness. Consider the following intertemporal utility function, with a constant elasticity of intertemporal substitution:

$$
U=\int_{0}^{\infty} \frac{C_{i}^{1-\sigma}-1}{1-\sigma} e^{-\rho t} d t
$$

where $C_{i t}$ denotes consumption at time $t$ by the representative individual living in unit $i$. For notational simplicity, we will drop the time subscript.

As before, the production function is given by equation (1). But now, unlike our previous analysis, we assume that individuais can increase the stock of $K_{i}$ : output can be converted in new units of $K_{i}$ one-to-one (to simplify, we assume no depreciation):

$$
\dot{K}_{i}=Y_{i}-C_{i}=r_{i} K_{i}+w_{i}-C_{i}
$$

where $r_{i}$ denotes capital rental and $w_{i}$ is total labor income.

From standard intertemporal optimization:

$$
\frac{\dot{C}_{i}}{C_{i}}=\frac{1}{\sigma}\left(r_{i}-\rho\right)
$$


Owners of $K_{i}$ are paid its marginal product. Since each unit of $K_{i}$ produces one unit of input $X_{i}$, we can write the marginal product of $K_{i}$ as follows:

$$
r_{i}=\frac{\partial Y_{i}}{\partial K_{i}}=\alpha A X_{i}^{\alpha-1}=\alpha A\left(Z_{i}^{d}\right)^{\alpha-1}=\alpha A\left[(1-\theta) S_{i}+\theta W\right]^{1-\alpha} K_{i}^{\alpha-1}
$$

where $Z_{i}^{d}$ is derived as in section 2.2 .

By substituting equation (13) into (12), we obtain the growth rate of consumption:

$$
\frac{\dot{C}_{i}}{C_{i}}=\frac{1}{\sigma}\left(\alpha A\left[(1-\theta) S_{i}+\theta W\right]^{1-\alpha} K_{i}^{\alpha-1}-\rho\right)
$$

Note that (14) is also the solution for the consumption path that would be chosen by a social planner who maximizes world welfare (taking $S_{i}$ as given). The steady state level of capital is given by:

$$
K_{i}^{s s}=\left(\frac{\alpha A}{\rho}\right)^{\frac{1}{1-\alpha}}\left[(1-\theta) S_{i}+\theta W\right]
$$

Assuming that all countries have equal size $S$, the steady state level of income will be:

$$
Y^{s s}=A^{\frac{1}{1-\alpha}}\left(\frac{\alpha}{\rho}\right)^{\frac{\alpha}{1-\alpha}}[(1-\theta) S+\theta W]
$$

Around the steady state, the growth rate of output can be approximated by:

$$
\frac{\dot{Y}}{Y}=\xi e^{-\xi}\left(\ln Y^{s s}-\ln Y(0)\right)
$$


where $\xi \equiv \frac{\rho}{2}\left[\left(1+\frac{4(1-\alpha)}{\alpha \sigma}\right)^{\frac{1}{2}}-1\right]$ and $Y(0)$ is initial income.

Equations (16) and (17) imply the following implication:

Proposition 1'. 'The growth rates of income (in the neighborhood of the steady state) and consumption are increasing in size $S$, increasing in trade openness $\theta$ and decreasing in size $S$ times openness $\theta$.

\section{Size, Openness and Growth.}

In this section, we provide empirical evidence consistent with the theory presented in Section 2. Table Ia displays parameter estimates for crosscountry growth regressions in which the rate of per capita GDP growth is regressed on openness, country size and the interaction of the two variables. In order to interpret this regression as a levels regression (in which lagged per capita income appears on the right-hand side), we added the log of initial per capita income as a regressor to this basic specification (Table $\Gamma \mathrm{b}$ ). Indeed, the control variables in this regression represent the determinants of the steady state level of income in "augmented" versions of the neoclassical growth model. ${ }^{8}$

Country size is measured either by the log of population or by the $\log$ of total GDP, while openness is measured by the ratio of imports plus exports to GDP. In Tables Ia and Ib we include no other controls; these are added in Tables IIa and IIb.

All of the results presented in Tables I and II are based on multivariate regression estimates, as in Barro and Sala-i-Martin (1995). The growth equation is formulated for each of six time periods (variables are averaged over 5-year periods, for 1960-64, 1965-69, ..., 1985-89), with coefficients constrained to equality across periods (the number of countries included in the

\footnotetext{
${ }^{8}$ We report results based on growth, but the relationship between 'levels' and 'growth' is well known: If $y_{i t}$ is GDP per capita at time $t$ in country $i$, we can write:

$\log y_{i t}-\log y_{i t-1}=\alpha+\beta \log y_{i t-1}+$ other controls.

This is the standard growth regression which allows for conditional convergence. One can rewrite this regression in levels:

$\log y_{i t}=\alpha+(\beta+1) \log y_{i t-1}+$ other controls.
} 
regressions is solely determined by data availability). The equations are estimated jointly, which allows for efficiency gains associated with error term correlations across periods for each country. Hence, the estimators used in this section are panel data-random effects estimators. In the SUR version of the estimates, we do not instrument for any of the right hand side variables, while the 3SLS version attempts to control for endogeneity bias induced by potential reverse causation between openness and growth (Frankel and Romer, 1995).

The instruments used for the 3SLS estimates are common 'gravity' variables such as land area, country size, terms of trade shocks, which are thought to affect the volume of a country's trade. To investigate whether these instruments can be validly excluded from the growth regression, we conducted exclusion restriction tests. These are based on the quasi-likelihood ratio (QLR) tests proposed by Gallant and Jorgenson (1979). QLR statistics are asymptotically distributed as chi-squared variables with degrees of freedom equal to the number of exclusions. Results from Table Ia and $\mathrm{Ib}$ show that the null hypothesis that the excluded instruments jointly do not belong in the growth regression cannot be rejected even at very low levels of confidence.

According to the theory presented in Section 2, we should expect the coefficients on size and openness to be positive, while the coefficient on their interaction should be negative. This is, in fact, precisely what we find. The sign and magnitude of the coefficients, which are highly significant statistically, are robust with respect to the two methods of estimation and to alternative measures of country size.

The estimates from Table Ia suggest that, for a hypothetical small country (that is, for log population equal to zero, or a population of one thousand), a 10 percentage point increase in the ratio of imports plus exports to GDP is associated with a 0.41 (SUR) to 0.75 (3SLS) percentage point increase in annual per capita growth, a large effect indeed (the standard deviation of the openness measure averaged over all time periods is $39 \%$ in our sample). These effects fall to 0.18 points of growth (SUR) and 0.34 (3SLS) when the $\log$ of population is 9.16 (the sample average, which corresponds to a country of 9.5 million inhabitants ). For a hypothetical closed country (zero trade), we find that a one standard deviation difference in the log of population (equal to 1.34 ) is positively associated with a 0.59 (SUR) to 1.09 
(3SLS) percentage point difference in growth. At the sample average openness level (i.e. for a trade to GDP ratio equal to $57.7 \%$ ), these effects fall to 0.40 points of growth (SUR) and 0.74 (3SLS) ${ }^{9}$. These rough orders of magnitude should only be taken as indicative, since we are obviously omitting important variables from the growth specification.

Tables IIa and IIb add additional controls to our basic regression in order to account for potential omitted variable bias. In the first table, country size is measured by the log of population, while in the second table it is measured by the $\log$ of total GDP. Both tables employ the SUR estimation methodology, but the results are qualitatively unchanged when using 3 SLS. $^{10}$ The additional conditioning variables are the 'basic' growth determinants usually considered in cross-country growth empirics, following, for instance, Barro and Sala-i-Martin (1995). We add these controls one at a time, in order to examine the robustness of our 'coefficients of interest', namely those that involve country size and openness. The sign, magnitude and statistical significance of these controls are consistent with past findings in the empirical growth literature: A higher rate of fertility, a higher level of governmentinduced price distortions (as proxied by the black market premium on the exchange rate) and a higher share of government consumption in GDP are all associated with lower growth rates. The pattern of human capital coefficients reproduces estimates in Barro and Sala-i-Martin (1995). We also find evidence of conditional convergence, as witnessed by the significantly negative effect of the $\log$ of per capita initial income.

As for the coefficients on the three variables that concern us, the results are robust with one exception. While the coefficient on openness and on the interaction of openness and size both remain significant through all of the specifications, the coefficient on country size alone becomes progressively less significant as one adds more controls (columns (4) and (5)). This should not be of great concern, since it just means that we are increasingly controlling for factors that are associated with the overall existence of increasing returns. In particular, country size and the government consumption ratio are negatively correlated, so that the inclusion of government size reduces the precision of the estimate on country size due to multicollinearity. ${ }^{11}$ In

\footnotetext{
${ }^{9}$ The effect of openness on growth never becomes negative, even when evaluated at the sample maximum of country size; however, the effect of size does become negative at extreme values of openness.

${ }^{10}$ Results are available upon request.

${ }^{11}$ On this point, see Alesina and Wacziarg (1997).
} 
other words, Table I indicates the existence of increasing returns (conditional on countries being closed to trade), while Table II may provide some indication that such increasing returns are correlated with common conditioning variables of cross-country growth regressions. On the other hand, the negative coefficient on the interaction of size and openness confirms the result that increasing returns with respect to country size are less and less important as countries become more open. In other words, open countries are able to reap the benefit of access to a large market, thereby avoiding the costs associated with being small.

\section{The number and size of countries}

\subsection{Heterogeneity and Country Size in the Static Model}

We now turn to the determination of the equilibrium number of countries. In a world described by the model of Section 2, everybody's income would be maximized if the entire world belonged to the same country, so that $S=W$ (recall equation (9)). ${ }^{12}$ This is clearly an extreme and uninteresting case since it ignores any costs associated with the excessive size of countries and the heterogeneity of their populations. Indeed, it seems clear that the British and Irish, Israeli and Arabs, Turks and Greeks, Tutsi and Hutu do not wish to belong to the same country, with the same governments, laws and public goods. We model this feature by assuming that each individual bears some heterogeneity costs $h($.$) which are a function of the size of the$ country:

$$
\begin{aligned}
& h(.)=h(S) \\
& h^{\prime}(.)>0 ; h^{\prime \prime}(.) \geq 0
\end{aligned}
$$

While it is a priori reasonable to assume that heterogeneity is not decreasing in the size of a country, there are obvious exceptions. Relatively small countries can be non-homogeneous (for example, Rwanda) while larger

\footnotetext{
${ }^{12}$ Only in the case of $\theta=1$, namely complete free trade, would the size of each country be uninfluential (equation (9)). Needless to say, if $S=W$, the trade regime, i.e., the value of $\theta$, is irrelevant.
} 
countries, in terms of population can be much more homogeneous (for example, Japan). Equation (18) is a rough reduced form for a model capturing the costs of heterogeneity. Alesina and Spolaore (1997) provide a model consistent with the reduced form in equation (18). In their model a group of heterogeneous individuals forming a country have to agree on a common set of public policies. Individuals are uniformly distributed on an ideological segment, so that the larger the country, the larger the average distance between the common policy adopted and each individual's preferred policy. In other words, average heterogeneity in each country is increasing in size. Equation (18) also implies that the cost function is weakly convex.

The most general formulation for the utility function, defined over consumption (which equals income in the static model) and heterogeneity costs, is $U(C, h)$. Without loss of generality, we assume that the utility function is separable in consumption and heterogeneity costs (in the Appendix we generalize the utility costs of heterogeneity without any qualitative changes in the results). In particular, we assume that the utility of an individual living in country $i$ is given by:

$$
U\left(C_{i}, h\left(S_{i}\right)\right)=\frac{C_{i}^{1-\sigma}-1}{1-\sigma}-h\left(S_{i}\right)
$$

Note that heterogeneity costs are identical for everyone regardless of their location within countries. We compute the optimal number of countries as if it were chosen by a social planner maximizing the sum of individual utilities.

We assume that the solution involves equal country sizes. This should follow naturally from the symmetric structure of the model. While we do not derive this as a result, one could extend the model in this direction, following, for example, Alesina and Spolaore (1997). ${ }^{13}$ The optimal number of countries chosen by the social planner is also the number of countries that would be selected unanimously by referendum, if the world population were asked to vote on the number of equally sized countries in the world. However, the optimal number of countries (chosen either by a social planner or by a

\footnotetext{
${ }^{13}$ The equal size assumption is made purely for analytical convenience. The model could be extended to allow for different parameters across different regions (for instance, different heterogeneity costs, barriers to trade or technologies), which would imply different country sizes in equilibrium.
} 
woridwide referendum) is not necessarily robust to unilateral secessions, an issue addressed below.

The country size $S^{*}$ that maximizes individual utility solves the following first order condition:

$$
(1-\alpha)(1-\theta) A^{1-\sigma} K^{\alpha(1-\sigma)}\left[(1-\theta) S^{*}+W \theta\right]^{(1-\alpha)(1-\sigma)-1}=h^{\prime}(.)
$$

where, as before, $\theta \equiv(1-\beta)^{\frac{\alpha}{1-\alpha}}$. Since $Y(S)$ is increasing and concave in $S$ and the function $h(S)$ is weakly convex, equation (20) admits one and only one solution, identified implicitly.

In order to obtain a closed form solution and gain more intuition, it is useful to first examine the case of linear heterogeneity costs, namely:

$$
h(S)=h S
$$

Using (20) and (21), we obtain the equilibrium country size $S^{*}$ :

$$
S^{*}=\frac{1}{1-\theta}\left[\left(\frac{(1-\alpha)(1-\theta)}{h A^{\sigma-1} K^{\alpha(\sigma-1)}}\right)^{\frac{1}{1-(1-\alpha)(1-\sigma)}}-\theta W\right]
$$

The equilibrium number of countries is then given by $N^{*}=W / S^{*} \cdot{ }^{14}$ From equation (22) one easily obtains the following:

Proposition 2: The equilibrium number of countries is: i) increasing in $h$; ii) decreasing in $A$ and $K$; and iii) increasing in $\theta$.

This result implies that countries should split up as heterogeneity costs increase and trade is liberalized. More specifically, Proposition 2 implies the following corollary which we explore empirically in Section 4:

Corollary: For given heterogeneity costs, the number of countries should increase with trade liberalization.

\footnotetext{
${ }^{14}$ We are abstracting from integer problems.
} 
In the Appendix, we extend our model to the case of a more general utility function in which individual utility $U(Y, h)$ is, not only nonlinear, but also not necessarily separable in $Y$ and $h$. The Appendix also explores the endogenous determination of country size in the context of the steady state of the dynamic model presented in Section 2. Since the equilibrium of the static model and the steady state of the dynamic model share the same properties with respect to country size and openness, Proposition 2 and its corollary, not surprisingly, do not change in the dynamic version.

\subsection{Unilateral Secessions}

We now allow for unilateral secessions and explore under what conditions will $S^{*}$ be "secession-free". More precisely, we investigate under what conditions, for a given $S^{*}$, no subset of regions would be willing to secede unilaterally and form an independent nation. For simplicity and without loss of generality, we assume that $\sigma=0$ and $K=1$ in this subsection.

When analyzing unilateral secessions, it is natural to assume that the regions contemplating a break away assume that all other borders will remain unchanged. Therefore, consider two alternative configurations of the world. In the first configuration, there exist $W / S^{*}$ nations, each of size $S^{*}$. In the second configuration, after a secession of size $\mathrm{Q}$ there exist one nation of size $Q$, one nation of size $S^{*}-Q$, and $W / S^{*}-2$ nations of size $S^{*}$. $S^{*}$ is secession-free if and only if, for any subset of regions $Q<S^{*}$, the citizens of the nation of size $Q$ in the second configuration of the world are not better off than in the first configuration of the world. Then the following proposition holds:

Proposition 3: $S^{*}$ is secession free if and only if $W\left(\frac{h}{(1-\alpha)(1-\theta)}\right)^{\frac{1}{\alpha}} \geq \Psi$ , where $\Psi$ is the unique solution of the equation $(1-\alpha+\alpha \Psi) \theta^{\alpha} \Psi^{\alpha}=1 .^{15}$

This means that for a given range of parameters (for $W, h$ and $\theta$ "large enough", that is $S^{*}$ "small enough"), $S^{*}$ is secession free. If $S^{*}$ is "too

\footnotetext{
${ }^{15}$ The proof of proposition 3 is available from the authors upon request.
} 
big" (because there is low heterogeneity and/or high barriers to international trade), some subset of the population might be better off seceding unilaterally. ${ }^{16}$

\subsection{Endogeneity of Trade Barriers}

In what precedes, we have assumed that the level of trade barriers $\beta$ is exogenous. In particular, we have assumed that barriers to international trade do not depend on the number and size of countries. We now relax this assumption and allow barriers to change as a function of country size. Indeed, trade barriers can be affected directly or indirectly by governments through tariffs, quotas, administrative barriers, choice of legal rules and standards, or other policy variables that may increase or reduce the costs of international exchanges. Country size is likely to have an effect on these policies. In particular, because of market size effects documented in Sections 2 and 3 , smaller countries may have incentives to adopt more open trade policies.

We do not model explicitly the political-economic mechanisms that determine $\beta$. Grossman and Helpman (1994), for instance, explicitly derive the level of trade protection as the result of lobbying and contributions by political interest groups. Presumably, the effectiveness of the arguments of these interest groups is negatively related to the potential costs of trade protection, which are themselves a function of country size. ${ }^{17}$ Hence, we directly assume that equilibrium barriers are determined by the following reduced-form equation:

$$
\beta=\beta_{0}+\gamma(S)
$$

In this specification, $\beta_{0}$ represents the "exogenous" portion of the barriers to international trade, related to the fact that such trade takes place between countries with different sets of legal, tax and institutional structures. $\gamma(S)$ represents the portion of trade barriers that is under more

\footnotetext{
${ }^{16}$ The result that the optimal size of nations may or may not be self-enforcing is similar to results by Alesina and Spolaore (1997).

${ }^{17}$ Spolaore (1995 and 1997) presents models in which barriers and sizes are jointly determined in equilibrium.
} 
direct control of policy makers (such as trade policy), and may thus respond to factors such as country size. If, ceteris paribus, the net benefits from lower barriers are higher for smaller countries (as we argued in Section 2 ), we would expect that, in equilibrium, $\beta$ would be increasing in $S$ : i.e., $\gamma(S)>0$. Under this assumption, and assuming for simplicity that $\sigma=0$, income $Y$ is still increasing in $S$ as long as:

$$
\gamma^{\prime}(S)<\frac{1-\alpha}{\alpha} \frac{1-\theta}{\theta} \frac{\theta^{\frac{1-\alpha}{\alpha}}}{W-S}
$$

Additional restrictions on the derivatives of $\gamma(S)$ would insure that $Y$ is a concave function of $S$. To fix ideas, consider the special case in which $\gamma(S)$ is linear: $\gamma(S)=\gamma S$, and $\alpha=1 / 2$. In this case, we have:

1) $Y(S)>0$ if and only if $\gamma<\frac{\beta_{0}}{W-2 S}$

2) $Y^{\prime \prime}(S)<0$ if and only if $\gamma<\frac{1}{4} \frac{\left(\beta_{0}-\gamma W+2 \gamma S\right)^{2}}{\left(1-\beta_{0}\right) W-\gamma W S+\beta_{0} S+\gamma S^{2}} \equiv M$

Clearly, 1) will hold for every $S$ if $\gamma \leq \frac{\beta_{0}}{W}$. If the above conditions are satisfied, we can obtain the equilibrium size $S^{*}$ exactly as in Section 4 , by solving: ${ }^{18}$

$$
\frac{\partial Y(S)}{\partial S}=\frac{d h(S)}{d S}
$$

Note that $\frac{d S^{*}}{d \beta_{0}}>0$ if and only if $\gamma<\sqrt{M}$, a condition that is certainly satisfied as long as 2) is satisfied and $M>1$.

The intuition for the above conditions is straightforward: our results for the exogenous case $(\gamma(S)=0)$ carry on to the case of endogenous tariffs as

${ }^{18}$ In the case of a more general utility function:

$$
\frac{d u\left[y\left(S^{*}\right), h\left(S^{*}\right)\right]}{d S^{*}}=\frac{\partial u}{\partial Y} Y\left(S^{*}\right)+\frac{\partial u}{\partial h} h\left(S^{*}\right)=0
$$

The second order condition is identical to [A.9]. Provided that $Y(S)$ is an increasing concave function, the second order condition is satisfied under those same assumptions about the first and second derivatives of $U(S, h)$ and $h(S)$ that we listed in the Appendix after equation [A.9]. 
long as the effect of $S$ on trade barriers is not "too large". It is interesting to note that, when the above conditions are satisfied,

a). Higher heterogeneity costs would lead to smaller nations and lower trade barriers.

b). An exogenous fall in trade barriers (lower $\beta_{0}$ ) may reduce overall trade barriers not only directly, but also indirectly (through $\gamma(S)$ ), by bringing about a smaller size $S$ in equilibrium.

Finally, note that in our model, the number and size of countries adjust smoothly to underlying changes in the parameters; in practice, border changes and secessions or unifications are costly and lengthy processes. This implies that we may observe border changes only when the underlying parameters have suffered a sufficiently large change. Also, to the extent that border changes are less costly when many borders are changing, the process of country formation and destruction may be lumpy rather than continuous. The end of major wars provides a good example of this fact. In the next section we show that, in fact, the process of country formation and secession was "lumpy" and occurred in geographical clusters.

\section{Country Formation, Secessions and Trade}

In this section we explore, with an historical excursion, the idea that the number of countries is related to the trade regime. In addition to trade and heterogeneity at least two other major factors influence country formation and destruction: military conflicts and the process of democratization. In the same spirit as the present paper, Alesina and Spolaore (1996) investigate the role of defense spending and wars for the equilibrium size of countries. Alesina and Spolaore (1997) study the effects of democratization. The first paper shows that secessions are likely to be more prevalent in a more peaceful world (i.e., with a lower probability of conflict), because the benefit of size for defense purposes becomes less important. The second paper shows that democratization should lead to secession, since dictatorial regimes maximize rents for the rulers by keeping together large countries formed by very different individuals who would want to separate, were they not forced together by the regime. Thus, one should find clusters of country creations as a consequence of wars, which is indeed the case (Figure I displays a surge 
in the number of countries after each of the two World Wars as well as after the end of the Cold War). Therefore, in what follows, we "hold constant", figuratively speaking, these other determinants of political secessions and unifications.

\subsection{Building Nation States}

The nation state, as we know it, is a relatively recent phenomenon. The widespread adoption of this political institution can be traced back to the first half of the 19th century, the period of triumph for the liberal ideas of Adam Smith. As the liberal theorists of the time knew well, nation-states are not necessary in a totally free market economy. Ideally, the world could be organized as a single free market area, a world market of free trading individuals. Nation-states were viewed as the second best, given the heterogeneity of individuals with different races, cultures and ideologies. According to liberal philosophy, a nation state had to be of sufficient size to form a viable unit of development but not more. In other words, given that a world of complete free trade was unattainable, countries had to reach a certain size in order for the national economy to be a viable unit of development. For example, the Dictionaire Politique of Garnier-Pagès, in 1843, described as 'ridiculous' that Belgium and Portugal should be independent nations because they were too small to be viable economies. ${ }^{19}$ Giuseppe Mazzini, one of the architects of Italian unification, thought that the optimal number of national states in Europe was 12, given economic considerations and the ethnic composition of Europe (Hobsbawm (1990), (1987)).$^{20}$ The unification of Italy (1861) and Germany (1871) can be viewed in this context as well: amongst other things, it was an attempt at building two economies of reasonable size, eliminating small polities protected by heavy trade barriers ${ }^{21}$. This was, to a large extent, facilitated by the relative cultural, linguistic and ethnic homogeneity of the groups that came together.

In fact, economic arguments were critical in the case of Germany's unification: As John Maynard Keynes put it, paraphrasing Bismarck, Germany

\footnotetext{
${ }^{19}$ This citation appears in Hobsbawm (1990).

${ }^{20}$ For instance, he did not take seriousty the nationalistic aspirations of Sicilians, Bretons, Weish and even the Irish, because he considered their economies to be too small

${ }^{21}$ On these two unifications, see in particular Tilly (1975).
} 
was unified by "coal and iron". ${ }^{22}$ The German Nation started in 1834 as a customs union (the Zollverein) which ensured low barriers to trade among its members. Participation in the customs union was viewed as an economic necessity for small and medium sized states which were too small to prosper without freer trade. As Breuilly (1996) notes, beyond this economic argument, "the German people were largely indifferent to the cause of national unity." To some extent, the pre-unification German customs union had some broad similarities with the current state of the European Union. Ex ante, it was not at all obvious that German unification would have progressed beyond an economic union, in much the same way that it is far from obvious that the current European Union will ever become a federal state. One reason why the European Union will most likely not follow the same fate as Germany is that it is characterized by a much greater degree of cultural and linguistic heterogeneity than pre-unification Germany.

In summary, European architects of the nation-state, in the first half of the 19th century, seemed to have in mind precisely the trade-off between the benefits of large economies and the costs of cultural heterogeneity.

\subsection{Empire Building}

The two decades which followed the unrest of 1848 in Europe witnessed a spectacular increase in trade and the diffusion of capitalism. The last three decades of the century were, instead, characterized by a much slower growth, and, in particular, the period 1873 to 1879 became known as the "Great Depression", until the 1930s. In the last three decades of the century, the degree of trade protection increased, while the volume of trade remained roughly constant. While complete and reliable data are hard to obtain for the period, Figure I shows that, in the period between 1870 and the First World War, the ratio of trade to GDP, in the few countries for which data are available, did not change much. Figure II shows that average tariff rates for countries with available data did not decline and, if anything, showed a tendency to increase between 1870 and 1915. At the same time, ethnic problems and separatist movements increasingly became a major factor in domestic and international politics. At the end of the Nineteenth Century, the trade-off between trade and ethnic conflict was being stretched: on the

\footnotetext{
${ }^{22}$ This citation is from Breuilly (1996).
} 
one hand, increasing protectionism and the need for larger markets to absorb a newly developed mass production required "large" countries; on the other hand various ethnic or linguistic minorities were becoming more restless. The answer to these tensions was flag waving patriotism, and the building of colonial empires. Flag waving was useful to unify heterogeneous citizens against outsiders. Colonialism was a way to expand markets and to secure sources of raw materials.

The connection between the Depression of the $1870 \mathrm{~s}$, the increase in protectionism, and the need for markets has been noted not only by several historians, but also by contemporary observers. "'If you were not such persistent protectionists', the British premier told the French ambassador in 1897, 'you would not find us so keen to annex territories"'(Hobsbawm (1987) page 67).

Similar considerations apply to American expansionism at the end of the Nineteenth Century. The conquests of Alaska, Hawaii, Samoa, Cuba and the Philippines (among other territories) between 1865 and 1898 was often justified in the Cnited States on the basis of the necessity to expand American markets and supply routes. British and French hegemony over much of the world put a limit on the United States' access to many markets, justifying in the eyes of American advocates of expansion an overseas pursuit of America's Manifest Destiny. ${ }^{23}$ In the colonial era, when political control limited the potential for economic interactions with large portions of the world, building an empire was the only way to secure markets and supply routes.

The Spanish and Portuguese empires are also good examples of empire building related to trade flows and market size. These two countries were largely dependent on trade with their colonies and, in fact, "imposed a trading monopoly and monopsony" with them (Bulmer-Thomas (1994)). In particular, the Spanish economy was "dangerously dependent" (Parry (1990)) on its trade with overseas colonies and greatly suffered when the empire collapsed at the beginning of the Nineteenth century. For national movements in Latin America in the first decades of the nineteenth century, political independence was viewed as necessary to break "the external trade monopoly... and have a chance to raise capital on the international market" (Bulmer-Thomas (1994)). In other words, "political consolidation [of newly

\footnotetext{
${ }^{23} \mathrm{On}$ this issue, see Wacziarg (1990) and the citations provided therein.
} 
independent countries] was...hastened by the prospect of economic progress through international trade." (Williamson (1992)). All of the newly independent countries in Latin America in the mid-nineteenth century adopted an outward looking strategy, reduced trade barriers and embraced a strategy of export-led growth: "By mid-century a consensus had emerged throughout the countries of Latin America in favor of export-led growth" (BulmerThomas, (1994)). ${ }^{24}$

In summary, building large empires, and waving the national flag around the world served the purpose of creating markets in a world of less than free trade, and kept cultural minorities in check.

\subsection{The Interwar Period}

This is not the place to discuss the causes of the First World War, which however, were not unrelated to the nationalistic problems of late 19 th century Europe. The end of the First World War opens the short 20th century. Figure III shows the number of countries created and destroyed in five year periods from 1870 until today. It excludes Sub-Saharan Africa, for which the identification of "countries" in the Nineteenth Century is somewhat problematic. The German unification, in which 18 previously independent entities disappeared, explains the dip at the beginning of Figure III. This figure also shows that very few new countries were created from 1875 to the Treaty of Versailles, while some countries disappeared. As was argued above, this was also a period of growing trade restrictions.

The same figure identifies a peak, i.e., a large number of countries created with the Treaty of Versailles in 1919. A common view amongst historians is that this treaty vastly mishandled the process of border redrawing after the First World War. Nevertheless, international borders hardly changed at all in the interwar period, until the late thirties, with the unfolding of the Second World War. In fact, Figure III shows that in the interwar period very

\footnotetext{
${ }^{24}$ Note, however, that the reliance on import duties as a source of fiscal revenue implied a lower bound on trade taxes, particularly because political instability and border disputes in the region had important fiscal consequences.
} 
few new countries appeared in the world. ${ }^{25}$ Figure IV, which includes SubSaharan Africa and begins in 1905, displays a similar pattern. This period also coincided with a collapse of international trade and a major upsurge of protectionist policies, largely as a response to the Great Depression.

\subsection{The Post Second World War Period}

In the fifty years that followed the Second World War, the number of independent countries exploded. As shown in Figure I, there were 64 independent countries in the world (outside Sub-Saharan Africa) in 1871, after the first German unification. This number declined slightly, to 59, until the First World War. In 1920, the world (including Sub-Saharan Africa) consisted of 69 countries. There were 89 in 1950 and 192 in 1995. As a consequence of this increase in the number of independent nations, the world now comprises a large number of relatively small countries: in 1995, 87 of the countries in the world had a population of less than 5 millions, of which, 58 had a population of less than 2.5 millions, and 35 less than 500 thousands!

Two major developments, after the border arrangements following the end of the Second World War, infuenced the process of country formation in the post-1945 era:

a) Decolonization in the developing world, particularly in Asia and SubSaharan Africa;

b) The collapse of the Soviet bloc, which may also be seen as a case of decolonization. ${ }^{26}$ In fact, this event led to the most significant episode of country creation in Europe since 1870.

Both phenomena are related to the dramatic increase in openness, international trade and the progressive reduction of policy-induced impediments

\footnotetext{
${ }^{25}$ Note that, among the very few new country creations, at least one, Egypt (independent in 1922) results from a classification problem: Egypt in 1922 was already largely independent from Britain, but its status switched from a protectorate to a semi-independent country. Leaving aside Vatican City, the only other countries created between 1920 and the Second World War were Ireland (1921), Mongolia (1921), Iraq (1932) and Saudi Arabia (1932) (although, again, Saudi Arabia was de facto independent since the mid-1920s).

${ }^{26}$ Note, however, that Eastern European countries were always classified as independent countries, even in the darkest periods of Soviet influence.
} 
to commerce. If Europe and the United States had reacted to the Second World War with the same retrenchment into protectionism as in the aftermath of the First World War, decolonization would probably have occurred much more slowly. If the former colonizers had been entangled in trade wars among themselves, their empires would have remained much more vital to them. It would also have been substantially more difficult for former Soviet Republics, some of them quite small, to break away after perestroika, had they expected to become economically isolated in a protectionist world. ${ }^{27}$ The same applies to the peaceful separation of Czechoslovakia which led to the creation of two new, rather small, independent countries. ${ }^{28}$ In fact, these new countries could follow the example of several economically successful small countries: Singapore, created in 1965, is indeed the quintessential example of a country with a borderless economy. The eagerness with which countries of the former Soviet bloc wish to enter the European Union adds credence to this idea. ${ }^{29}$ Note that the pattern of trade of former Soviet Republics and Eastern European countries has changed substantially after the break-up of the Soviet Union. Trade flows between these countries and the West have increased dramatically. ${ }^{30}$ In a world of high trade barriers, the former Soviet republics would have experienced much greater difficulties in redirecting their trade.

At first glance, the process leading to a European Union could be seen as contrary to the thrust of our argument, because several major countries are 'unifying' in a period of increasing economic integration and trade liberalization. This interpretation would be superficial. The European Union will never be a classical nation-state. At most, it will be a loose federation of independent states, joined in a common currency area, coordinated macroeconomic policies to support this common currency, in addition to a free trade area supplemented by a harmonization of regulations and standards.

\footnotetext{
${ }^{27}$ For example, Latvia has a population of less than 3 million, Estonia of about 1.5 million, and the Kyrgyz Republic of less than 5 million. For a recent in depth discussion of nationalism and ethnicity in Eastern Europe, see Brubaker (1990).

${ }^{28}$ The Czech Republic has about 10 million inhabitants, and the Slovak Republic about 5 million.

${ }^{29}$ For instance, Bugajski (1993) writes that: "The objective of every Eastern European state is full incorporation in all multilateral European institutions...Economic integration would provide many tangible benefits related to trade."

${ }^{30}$ See the data presented by Michalopoulos and Torr (1992) and Van Selm (1997). For a discussion of economic reforms following the Soviet coup of 1991, see Nordhaus, Peck and Richardson (1991).
} 
In fact, while economic integration is progressing at the European level, regional separatism is more and more vocal in several member countries of the Union, such as Spain, Belgium, Italy and even France. ${ }^{31}$ So much so, that many an observer has argued that Europe will (and, perhaps should) become a collection of regions (Brittany, the Basque Region, Scotland, Catalonia, etc.) loosely connected within a European federation. ${ }^{32}$ The motivation of these developments is consistent with our argument: linguistic, ethnic and cultural minorities feel that they are economically "viable" in the context of a truly European common market, thus they can "safely" separate from the home country. In other words, the nation-state in Europe is threatened from above because of the necessity of developing supranational juridical institutions, and from below because of rampant regional movements. These movements feel they do not really need Madrid, Rome or Paris, when they can be loosely associated to the "Europe of Regions" politically, and be fully integrated in the Union economically. Newhouse (1997) puts it rather starkly: "[In Europe], the nation-state is too big to run everyday life and too small to manage international affairs."

Similar considerations apply to Québec's separatism in the context of NAFTA. In fact, an important issue in the discussion of Québec's independence is how this region benefits, in terms of trade flows, from being part of Canada relative to being an independent country in NAFTA. In studying precisely this point both McCallum (1995), and Helliwell (1996) conclude that, at least for Canada, national borders still matter, so that trade among Canadian provinces is ceteris paribus much easier than between Canadian provinces and US states. This implies that there might be a cost for Québec in terms of trade flows if it were to become independent. Such arguments were made by the proponents of the "no" in the self-determination referendum of 1996. As the perceived economic costs of secession fall with greater North American economic integration, the likelihood of Québec gaining independence can be expected to increase. In fact, the development of a truly free-trade area in North America might reduce these costs and make Québec's separatism more attractive.

In the post-war period the only major example of reunification, i.e., of a change apparently inconsistent with increasing trade liberalization, is Ger-

\footnotetext{
${ }^{31}$ For a recent discussion of "rising regionalism" in Europe, see Newhouse (1997).

${ }^{32}$ See Drèze (1991) on this point.
} 
man reunification. ${ }^{33}$ Clearly, this change corrected an artificial division of this country following its military defeat, and had largely political and cultural motivations. Even so, the economic costs of reunification have been quite substantial and have led a good portion of the public in the former Federal Republic to question the reunification. In particular, this illustrates one aspect of our trade-off, namely that a culturally homogeneous country will tend to remain "in one piece", even in a period of increased integration. Similarly, a country that has broken up for extraneous reasons can be expected to reunite at some point: once the force that generated the initial division (namely the Cold War) was no longer in place, there was no constraint to the "natural" reunification of Germany. ${ }^{34}$

Finally, the last two decades have witnessed, not only an increase in openness and international trade, but also the transformation of some sectors of the economy into real transnational economies. Indeed, in a truly global and integrated world economy, one does not need traditional nation-states. On the other hand, one needs to develop supranational legislation and courts to enforce contracts and facilitate economic activities that transcend national boundaries. ${ }^{35}$

\section{Conclusion}

Trade liberalization and average country size are inversely related. The 'globalization' of markets goes hand in hand with political separatism.

While this paper has emphasized the link from trade regime to country size, one may argue that the opposite channel may also be operative; namely a world of small countries has to adopt a relatively free trade regime, because this is in the interest of small countries. The two channels are not

\footnotetext{
${ }^{33}$ There were others, such as the reunification of North and South Vietnam in 1975, the reunification of South and North Yemen in 1992, among very few examples. In all of these, very homogeneous populations were reunited after separations that were largely due to extraneous political factors.

${ }^{34}$ Along these lines, the reunification of South and North Korea appears as a very likely event. Predicting its date is another matter altogether; this largely depends on the evolution of domestic politics in China, in much the same way German reunification depended on the collapse of Soviet authority.

${ }^{35}$ For a recent discussion of this and related points, see Mathews (1997). For a more formal treatment see Casella and Feinstein (1990).
} 
mutually exclusive. Suppose that a certain region (say, Québec, Catalonia, Ukraine, etc.) considers demanding independence. Each of these regions takes the trade regime in the world, at the moment of their declaration of independence, as given. However, if the process of political separatism continues, and average country size declines, more and more 'players' in the international arena have an interest in preserving free trade, thus reinforcing the movement toward trade liberalization that may have influenced their decision about secession in the first place.

An implication of this paper is that as the process of economic 'globalization' will progress, political separatism will continue to be alive and well. The concept of relatively large and centralized nation-states is and will be more and more threatened by regional separatism from below, and the growth of supranational institutions from above, in a world of 'global' markets. 


\section{Appendix}

In this appendix we briefly discuss simple derivations and extensions for the basic model.

\section{Derivation of equations (4) and (5)}

Call $P_{j i}$ the price of input $j$ in units of final output, to be paid to the owners of input $j$ for the shipping of one unit of input $j$ to unit $i$. When $Z$ units of input $j$ are shipped to unit $i$, the amount available for production will be $Z$ if units $i$ and $j$ belong to the same country, $(1-\beta) Z$ if units $i$ and $j$ belong to different countries. Denote with $i^{\prime}$ a unit belonging to the same country as unit $j$, and with $i^{\prime \prime}$ a unit that belongs to a different country.

As each input is paid its marginal product, in equilibrium we have:

$$
\begin{gathered}
A \alpha Z_{j i^{\prime}}^{\alpha-1}=P_{j i^{\prime}} \text { for all } i^{\prime} \\
A(1-\beta)^{\alpha} \alpha Z_{j i^{\prime \prime}}^{\alpha-1}=P_{j i^{\prime \prime}} \text { for all } i^{\prime \prime}
\end{gathered}
$$

As the price of one unit of input $j$ is the same no matter where it is shipped (no tariffs or other forms of price discrimination), we have that [A1] $=[\mathrm{A} 2]=P_{j}$, and therefore:

1) All units belonging to the same country as unit $j$ receive the same amount of input $j$ (call it $Z_{j}^{d}$, where $Z_{j}^{d}=Z_{j i^{\prime}}$ for all $i^{\prime}$ );

2) All units that do not belong to the same country as unit $j$ receive the same amount of input $j$ (call it $Z_{j}^{f}$, where $Z_{j}^{f}=Z_{j i}$, for all $i^{\prime \prime}$ ), and the following relationship holds:

$$
\frac{Z_{j}^{f}}{Z_{j}^{d}}=(1-\beta)^{\frac{\alpha}{1-\alpha}} \equiv \theta
$$


The resource constraint for each input is:

$$
S_{i} Z_{j}^{d}+\left(W-S_{i}\right) Z_{j}^{f}=K
$$

Equations [A3] and [A4] imply equations (4) and (5) in the text. It can be easily shown that (4) and (5) are also the solutions for a social planner who maximizes world output.

\section{Transportation Costs}

Suppose now that $\delta>0$, so that Assumption A2 is relaxed. The amount of input that unit $i$ ships domestically is now given by:

$$
Z_{i}^{d}=\frac{(1-\delta)^{\frac{\alpha}{1-\alpha}} K}{1+(1-\delta)^{\frac{\alpha}{1-\alpha}}(S-1)+(W-S)[(1-\delta)(1-\beta)]^{\frac{\alpha}{1-\alpha}}}
$$

The amount of intermediate good that unit i ships abroad is given by:

$$
Z_{i}^{f}=\frac{[(1-\delta)(1-\beta)]^{\frac{\alpha}{1-\alpha}} K}{1+(1-\delta)^{\frac{\alpha}{1-\alpha}}(S-1)+(W-S)[(1-\delta)(1-\beta)]^{\frac{\alpha}{1-\alpha}}}
$$

Using equations [A5] and [A6] instead of (4) and (5) in the text, one can derive all of our previous results, which remain qualitatively unchanged.

\section{Generalization of the Utility Costs of Heterogeneity}

$\frac{C_{i}^{1-\sigma} \cdot 1}{1-\sigma}-h$ is a special case of the more general utility function $U(C, h)$, where:

$$
U_{C}>0 \text { and } U_{h}<0
$$

The first order condition $U(S)=U_{C} \frac{d C}{d S}+U_{h} h(S)=0$ identifies the unique optimal size $S^{*}=U^{-1}$ as long as: 


$$
1 \leq U^{-1} \leq W
$$

and:

$$
U^{\prime \prime}(S)=U_{C C}\left(\frac{d C}{d S}\right)^{2}+2 U_{C h} \frac{d C}{d S} h+U_{h h}(h)^{2}+U_{C} \frac{d^{2} C}{d S^{2}}+U_{h} h^{\prime \prime}<0
$$

As $C(S)$ and $h(S)$ are both increasing in $S$, and $C(S)$ is concave for nonzero trade barriers, [A9] holds if the following three sufficient conditions are simultaneously satisfied:

1) $[\mathrm{A} 7]$;

2) $h^{\prime \prime} \geq 0$; and

3) All second derivatives of $U$ are nonpositive, i.e.:

$$
U_{C C} \leq 0 ; U_{h h} \leq 0 ; U_{C h} \leq 0
$$

\section{The Number of Countries in a Dynamic Framework}

If we revert to the dynamic model of Section 2.3 , the determination of the number of countries can be obtained by introducing heterogeneity costs in the instantaneous utility function:

$$
U\left(C_{i}, h_{i}\right)=\int_{0}^{\infty}\left(\frac{C_{i}^{1-\sigma}-1}{1-\sigma}-h_{i}\right) d t
$$

where $h_{i}$ denotes heterogeneity costs at time $t$ in region $i$. As in Section 4.1 , these heterogeneity costs enter in a linear and separable fashion. In principle, one could now derive an optimal path for $S_{i t}$, that would depend, among other things, on the costs of changing borders. We limit our analysis to steady-states and equal country sizes in order to determine the optimal 
$S^{*}$. Since we have assumed away depreciation, technological progress and population growth, the steady-state level of consumption is equal to the steady-state level of income, that is:

$$
C^{s s}=Y^{s s}=A^{\frac{1}{1-\alpha}}\left(\frac{\alpha}{\rho}\right)^{\frac{\alpha}{1-\alpha}}[(1-\theta) S+\theta W]
$$

Note that Proposition 1 applies to steady state levels of consumption and income. Hence, $S^{*}$ is given by:

$$
\frac{d}{d S}\left[\frac{\left[Y^{S S}\left(S^{*}\right)\right]^{1-\sigma}-1}{1-\sigma}\right]=h^{\prime}\left(S^{*}\right)
$$

For instance, if $h(S)$ is linear and equal to $h S$, we obtain:

$$
S^{*}=\frac{A_{0}(1-\theta)^{\frac{1-\sigma}{\sigma}}}{h^{\frac{1}{\sigma}}}-\frac{\theta}{1-\theta} W
$$

where:

$$
A_{0}^{\frac{\sigma}{1-\sigma}} \equiv A^{\frac{1}{1-\alpha}}\left(\frac{\alpha}{\rho}\right)^{\frac{\alpha}{1-\alpha}}
$$

As in the static case, the following result holds:

Proposition 2'. The number of countries $N^{*}=W / S^{*}$ is negatively related to trade openness $\theta$. 


\section{Table Ia: Growth regressions including country size, openness and their interaction. \\ Basic Specification (without any controls)}

\begin{tabular}{|c|c|c|c|c|}
\hline \multirow{2}{*}{$\begin{array}{c}\text { Dependent Variable: } \\
\text { Growth of per capita } \\
\text { GDP (\%) } \\
\end{array}$} & Country Size $=$ & Log of Total GDP & Country Size $=$ & Log of Population \\
\hline & 3SLS* & SUR / GLS & 3SLS* & SUR / GLS \\
\hline Constant & $\begin{array}{r}-7.963 \\
(-3.42)\end{array}$ & $\begin{array}{r}-4.242 \\
(-2.63)\end{array}$ & $\begin{array}{l}-7.383 \\
(-2.78) \\
\end{array}$ & $\begin{array}{r}-2.866 \\
(-1.91)\end{array}$ \\
\hline Trade/GDP ratio & $\begin{array}{r}0.066 \\
(4.87) \\
\end{array}$ & $\begin{array}{r}0.039 \\
(6.11)\end{array}$ & $\begin{array}{r}0.075 \\
(4.02)\end{array}$ & $\begin{array}{r}0.041 \\
(5.55)\end{array}$ \\
\hline Size* openness & $\begin{array}{r}-0.0021 \\
(-4.80)\end{array}$ & $\begin{array}{r}-0.0012 \\
(-4.71)\end{array}$ & $\begin{array}{r}-0.0045 \\
(-4.63)\end{array}$ & $\begin{array}{r}-0.0025 \\
(-4.56)\end{array}$ \\
\hline Country Size & $\begin{array}{r}0.496 \\
(4.09) \\
\end{array}$ & $\begin{array}{r}0.325 \\
(\mathbf{3 . 5 7}) \\
\end{array}$ & $\begin{array}{r}0.814 \\
(3.57)\end{array}$ & $\begin{array}{r}0.443 \\
(3.04)\end{array}$ \\
\hline Adj. R-squared & $\begin{array}{l}.04 .12 .18 \\
.09 .17 .16 \\
\end{array}$ & $\begin{array}{l}.04 .12 .17 \\
.09 .17 .17\end{array}$ & $\begin{array}{l}.01 .11 .18 \\
.10 .18 .14\end{array}$ & $\begin{array}{l}.01 .11 .18 \\
.10 .18 .14\end{array}$ \\
\hline QLR stat $(\mathrm{DF}=7)$ & 8.02 & & 3.14 & \\
\hline$\chi^{2}$ critical value $(95 \%)$ & 14.07 & & 14.07 & \\
\hline
\end{tabular}

(t-statistics based on heteroskedastic-consistent (White-robust) standard errors in parentheses)

Number of Observations $=84$

* Instruments are: Terms of trade shocks (all 6 periods), log of land area, island dummy, small island dummy, small country dummy, landlocked country dummy, log initial income (all periods), log country size (as measured in relevant columns, all periods). 
Table Ib. Growth regressions including country size, openness and their interaction.

Basic Specification (includes the log of initial income)

\begin{tabular}{|c|c|c|c|c|}
\hline \multirow{2}{*}{$\begin{array}{c}\text { Dependent Variable: } \\
\text { Growth of per capita } \\
\text { GDP }(\%)\end{array}$} & \multicolumn{2}{|c|}{ Country Size $=$ Log of Population } & \multicolumn{2}{|c|}{ Country Size $=$ Log of Total GDP } \\
\hline & 3SLS & SUR/GLS & $3 \mathrm{SLS}$ & SUR/GLS \\
\hline Constant & $\begin{array}{l}-7.907 \\
(-3.07) \\
\end{array}$ & $\begin{array}{l}-4.066 \\
(-2.52) \\
\end{array}$ & $\begin{array}{l}-8.166 \\
(-3.17)\end{array}$ & $\begin{array}{l}-4.177 \\
(-2.59)\end{array}$ \\
\hline $\begin{array}{l}\text { Log per capita } \\
\text { initial income }\end{array}$ & $\begin{array}{r}0.081 \\
(0.52) \\
\end{array}$ & $\begin{array}{r}0.192 \\
(1.44) \\
\end{array}$ & $\begin{array}{l}-0.598 \\
(-2.03)\end{array}$ & $\begin{array}{l}-0.156 \\
(-0.74)\end{array}$ \\
\hline Openness ratio & $\begin{array}{r}0.075 \\
(3.94) \\
\end{array}$ & $\begin{array}{r}0.040 \\
(5.46)\end{array}$ & $\begin{array}{r}0.075 \\
(4.00)\end{array}$ & $\begin{array}{r}0.040 \\
(5.53)\end{array}$ \\
\hline Openness*size & $\begin{array}{r}-0.0045 \\
(-4.72) \\
\end{array}$ & $\begin{array}{r}-0.0025 \\
(-4.68) \\
\end{array}$ & $\begin{array}{r}-0.0022 \\
(-4.60) \\
\end{array}$ & $\begin{array}{r}-0.0012 \\
(-4.65) \\
\end{array}$ \\
\hline Country size & $\begin{array}{r}0.807 \\
(3.45) \\
\end{array}$ & $\begin{array}{r}0.418 \\
(2.89) \\
\end{array}$ & $\begin{array}{r}0.754 \\
(3.42) \\
\end{array}$ & $\begin{array}{r}0.388 \\
(2.75) \\
\end{array}$ \\
\hline Adj. R-squared & $\begin{array}{l}.02 .11 .17 \\
.10 .18 .15 \\
\end{array}$ & $\begin{array}{l}.03 .11 .16 \\
.09 .18 .17 \\
\end{array}$ & $\begin{array}{l}.02 .12 .19 \\
.10 .18 .15 \\
\end{array}$ & $\begin{array}{l}.03 .12 .18 \\
.10 .18 .17 \\
\end{array}$ \\
\hline QLR Statistic $(\mathrm{DF}=6)$ & 3.09 & - & 2.81 & - \\
\hline$\chi^{2}$ crit. value $(95 \%)$ & 12.59 & & 12.59 & \\
\hline
\end{tabular}

(t-statistics based on heteroskedastic-consistent standard errors (White-robust) in parentheses)

Number of Observations $=84$

* Instruments are: Terms of trade shocks (all 6 periods), log of land area, island dummy, small island dummy, small country dummy, landlocked country dummy, log initial income (all periods), log country size (as measured in relevant columns, all periods). 
Table IIa. Robustness analysis. Size $=$ Log of Population

\begin{tabular}{|c|c|c|c|c|c|}
\hline $\begin{array}{l}\text { Dependent Variable: } \\
\text { Growth of per } \\
\text { Capita GDP (\%) }\end{array}$ & (1) & $(2)$ & (3) & (4) & (5) \\
\hline Constant & $\begin{array}{r}5.771 \\
(1.76)\end{array}$ & $\begin{array}{r}5.442 \\
(1.77)\end{array}$ & $\begin{array}{r}5.277 \\
(1.75)\end{array}$ & $\begin{array}{l}8.366 \\
(3.00)\end{array}$ & $\begin{array}{l}10.659 \\
(4.42)\end{array}$ \\
\hline $\begin{array}{l}\text { Log per capita } \\
\text { initial income }\end{array}$ & $\begin{array}{r}-0.649 \\
(-2.34)\end{array}$ & $\begin{array}{l}-0.525 \\
(-1.89)\end{array}$ & $\begin{array}{l}-0.481 \\
(-1.75)\end{array}$ & $\begin{array}{l}-0.641 \\
(-2.49)\end{array}$ & $\begin{array}{l}-1.409 \\
(-5.73)\end{array}$ \\
\hline Openness ratio & $\begin{array}{r}0.036 \\
(4.67)\end{array}$ & $\begin{array}{r}0.033 \\
(4.59)\end{array}$ & $\begin{array}{r}0.033 \\
(4.74)\end{array}$ & $\begin{array}{r}0.030 \\
(4.30)\end{array}$ & $\begin{array}{r}0.021 \\
(4.02)\end{array}$ \\
\hline Openness*size & $\begin{array}{r}-0.0025 \\
(-4.62)\end{array}$ & $\begin{array}{r}-0.0026 \\
(-4.59)\end{array}$ & $\begin{array}{r}-0.0025 \\
(-4.58)\end{array}$ & $\begin{array}{r}-0.0022 \\
(-4.23)\end{array}$ & $\begin{array}{r}-0.0017 \\
(-3.82)\end{array}$ \\
\hline Country size & $\begin{array}{r}0.374 \\
(2.69)\end{array}$ & $\begin{array}{r}0.287 \\
(2.22)\end{array}$ & $\begin{array}{r}0.263 \\
(2.02)\end{array}$ & $\begin{array}{r}0.203 \\
(1.66)\end{array}$ & $\begin{array}{r}0.152 \\
(1.38)\end{array}$ \\
\hline Fertility rate & $\begin{array}{r}-0.595 \\
(-3.89)\end{array}$ & $\begin{array}{l}-0.578 \\
(-4.17)\end{array}$ & $\begin{array}{l}-0.543 \\
(-3.99)\end{array}$ & $\begin{array}{l}-0.506 \\
(-4.02)\end{array}$ & $\begin{array}{l}-0.253 \\
(-1.98)\end{array}$ \\
\hline $\begin{array}{l}\text { Male human } \\
\text { capital }\end{array}$ & - & $\begin{array}{r}1.224 \\
(2.64)\end{array}$ & $\begin{array}{r}1.149 \\
(2.39)\end{array}$ & $\begin{array}{r}1.019 \\
(2.20)\end{array}$ & $\begin{array}{r}0.839 \\
(1.95)\end{array}$ \\
\hline $\begin{array}{l}\text { Female human } \\
\text { capital }\end{array}$ & - & $\begin{array}{l}-1.389 \\
(-3.08)\end{array}$ & $\begin{array}{l}-1.359 \\
(-2.93)\end{array}$ & $\begin{array}{l}-1.227 \\
(-2.77)\end{array}$ & $\begin{array}{l}-0.861 \\
(-2.02)\end{array}$ \\
\hline $\begin{array}{l}\text { Black market } \\
\text { premium }\end{array}$ & - & - & $\begin{array}{r}-0.001 \\
(-5.44)\end{array}$ & $\begin{array}{l}-0.001 \\
(-5.07)\end{array}$ & $\begin{array}{l}-0.001 \\
(-6.33)\end{array}$ \\
\hline $\begin{array}{l}\text { Government share } \\
\text { of GDP }\end{array}$ & - & - & - & $\begin{array}{r}-0.074 \\
(-3.33)\end{array}$ & $\begin{array}{l}-0.063 \\
(-2.60)\end{array}$ \\
\hline Investment rate & - & - & - & - & $\begin{array}{r}0.172 \\
(6.41)\end{array}$ \\
\hline Adj. R-squared & $\begin{array}{l}.06 .19 .09 \\
.05 .22 .38\end{array}$ & $\begin{array}{l}.07 .22 .12 \\
.08 \quad .25 .34 \\
\end{array}$ & $\begin{array}{ll}.07 .22 & .13 \\
.10 & .25 .32 \\
\end{array}$ & $\begin{array}{l}.08 .25 .20 \\
.06 .23 .34\end{array}$ & $\begin{array}{lll}.10 & .35 & .34 \\
.12 & .24 & .34\end{array}$ \\
\hline Log likelihood & -1228.60 & -1224.49 & -1218.49 & -1212.52 & -1183.67 \\
\hline
\end{tabular}

(t-statistics based on heteroskedastic-consistent (White robust) standard errors in parentheses) \# of Observations: 84.

Estimation Method: SUR/GLS. Results (available upon request) are qualitatively unchanged when using 3SLS. 
Table IIb. Robustness analysis. Size $=\log$ of Total GDP

\begin{tabular}{|c|c|c|c|c|c|}
\hline $\begin{array}{l}\text { Dependent Variable: } \\
\text { Growth of per } \\
\text { Capita GDP (\%) }\end{array}$ & (1) & (2) & (3) & (4) & (5) \\
\hline Constant & $\begin{array}{r}5.672 \\
(1.73) \\
\end{array}$ & $\begin{array}{r}5.372 \\
(1.74) \\
\end{array}$ & $\begin{array}{r}5.217 \\
(1.72) \\
\end{array}$ & $\begin{array}{r}8.333 \\
(2.98) \\
\end{array}$ & $\begin{array}{r}10.655 \\
(4.40) \\
\end{array}$ \\
\hline $\begin{array}{l}\text { Log per capita } \\
\text { initial income }\end{array}$ & $\begin{array}{l}-0.957 \\
(-3.11)\end{array}$ & $\begin{array}{l}-0.748 \\
(-2.44)\end{array}$ & $\begin{array}{r}-0.681 \\
(-2.22)\end{array}$ & $\begin{array}{l}-0.790 \\
(-2.65)\end{array}$ & $\begin{array}{l}-1.522 \\
(-5.75)\end{array}$ \\
\hline Openness ratio & $\begin{array}{r}0.036 \\
(4.74)\end{array}$ & $\begin{array}{r}0.033 \\
(4.62)\end{array}$ & $\begin{array}{r}0.032 \\
(4.76)\end{array}$ & $\begin{array}{r}0.030 \\
(4.30)\end{array}$ & $\begin{array}{r}0.021 \\
(4.04)\end{array}$ \\
\hline Openness* size & $\begin{array}{r}-0.0012 \\
(-4.56) \\
\end{array}$ & $\begin{array}{r}-0.0012 \\
(-4.43) \\
\end{array}$ & $\begin{array}{r}-0.0012 \\
(-4.42)\end{array}$ & $\begin{array}{r}-0.0011 \\
(-4.11)\end{array}$ & $\begin{array}{r}-0.0008 \\
(-3.81)\end{array}$ \\
\hline Country size & $\begin{array}{r}0.346 \\
(2.56) \\
\end{array}$ & $\begin{array}{r}0.258 \\
(2.07) \\
\end{array}$ & $\begin{array}{r}0.235 \\
(1.86) \\
\end{array}$ & $\begin{array}{r}0.178 \\
(1.49) \\
\end{array}$ & $\begin{array}{r}0.133 \\
(1.24)\end{array}$ \\
\hline Fertility rate & $\begin{array}{r}-0.597 \\
(-3.87) \\
\end{array}$ & $\begin{array}{r}-0.580 \\
(-4.14) \\
\end{array}$ & $\begin{array}{r}-0.545 \\
(-3.97) \\
\end{array}$ & $\begin{array}{l}-0.508 \\
(-4.00)\end{array}$ & $\begin{array}{r}-0.253 \\
(-1.97)\end{array}$ \\
\hline $\begin{array}{l}\text { Male human } \\
\text { capital }\end{array}$ & - & $\begin{array}{r}1.192 \\
(2.59) \\
\end{array}$ & $\begin{array}{r}1.115 \\
(2.35) \\
\end{array}$ & $\begin{array}{r}0.988 \\
(2.16) \\
\end{array}$ & $\begin{array}{r}0.817 \\
(1.91) \\
\end{array}$ \\
\hline $\begin{array}{l}\text { Female human } \\
\text { capital }\end{array}$ & - & $\begin{array}{l}-1.355 \\
(-3.03)\end{array}$ & $\begin{array}{l}-1.324 \\
(-2.88)\end{array}$ & $\begin{array}{l}-1.194 \\
(-2.72)\end{array}$ & $\begin{array}{l}-0.838 \\
(-1.97)\end{array}$ \\
\hline $\begin{array}{l}\text { Black market } \\
\text { premium }\end{array}$ & - & - & $\begin{array}{r}-0.001 \\
(-5.50) \\
\end{array}$ & $\begin{array}{l}-0.001 \\
(-5.12) \\
\end{array}$ & $\begin{array}{r}-0.001 \\
(-6.37)\end{array}$ \\
\hline $\begin{array}{l}\text { Government } \\
\text { share of GDP }\end{array}$ & - & - & - & $\begin{array}{l}-0.075 \\
(-3.32)\end{array}$ & $\begin{array}{l}-0.064 \\
(-2.61)\end{array}$ \\
\hline Investment rate & - & - & - & - & $\begin{array}{r}0.172 \\
(6.37) \\
\end{array}$ \\
\hline Adj. R-squared & $\begin{array}{l}.06 .19 .10 \\
.06 .22 .39 \\
\end{array}$ & $\begin{array}{l}.07 .22 .12 \\
.09 .25 .35 \\
\end{array}$ & $\begin{array}{l}.07 .22 .14 \\
.10 .24 .33 \\
\end{array}$ & $\begin{array}{l}.07 .25 .21 \\
.06 \quad .22 .34\end{array}$ & $\begin{array}{lll}.10 .35 .35 \\
.12 & .24 .34\end{array}$ \\
\hline Log likelihood & -1228.45 & -1224.56 & -1218.57 & -1212.54 & -1183.80 \\
\hline
\end{tabular}

(t-statistics based on heteroskedastic-consistent (White robust) standard errors in parentheses) \# of Observations: 84

Estimation Method: SUR/GLS. Results (available upon request) are qualitatively unchanged when using 3SLS. 
Table III. Summary Statistics for $1960-89$ sample averages

\begin{tabular}{|l|r|r|r|r|}
\hline \multicolumn{1}{|c|}{ Variable } & Mean & Std. Dev. & Minimum & Maximum \\
\hline \hline Growth in per capita GDP (\%) & 2.384 & 1.708 & -0.556 & 6.730 \\
\hline Log initial per capita income (\%) & 7.842 & 0.949 & 6.062 & 9.499 \\
\hline Trade to GDP ratio (\%) & 57.689 & 39.037 & 12.648 & 306.901 \\
\hline Male human capital & 1.232 & 1.001 & 0.095 & 4.844 \\
\hline Female human capital & 0.871 & 0.920 & 0.021 & 4.695 \\
\hline Fertility rate & 4.848 & 1.891 & 1.892 & 7.988 \\
\hline Government consumption / GDP (\%) & 17.594 & 6.789 & 6.097 & 39.445 \\
\hline Investment rate (\%) & 17.646 & 7.812 & 2.453 & 34.843 \\
\hline Log of land area & 5.457 & 1.772 & 0.000 & 9.208 \\
\hline Log of population & 9.160 & 1.338 & 6.417 & 13.287 \\
\hline Black market premium (\%) & 52.226 & 237.574 & -0.564 & 2146.655 \\
\hline Log total GDP & 17.032 & 1.764 & 13.604 & 21.771 \\
\hline \hline
\end{tabular}

Number of Observations: 84

List of Countries (Section 3 regressions)

$\begin{array}{lllll}\text { Algeria } & \text { Cyprus } & \text { Iraq } & \text { Nicaragua } & \text { Syria } \\ \text { Argentina } & \text { Denmark } & \text { Ireland } & \text { Niger } & \text { Taiwan } \\ \text { Australia } & \text { Dominican Rep. } & \text { Israel } & \text { Norway } & \text { Tanzania } \\ \text { Austria } & \text { Ecuador } & \text { Italy } & \text { Pakistan } & \text { Thailand } \\ \text { Bangladesh } & \text { El Salvador } & \text { Jamaica } & \text { Panama } & \text { Togo } \\ \text { Belgium } & \text { Finland } & \text { Japan } & \text { Paraguay } & \text { Tunisia } \\ \text { Benin } & \text { France } & \text { Jordan } & \text { Peru } & \text { Turkey } \\ \text { Bolivia } & \text { Germany, Fed. Rep. } & \text { Kenya } & \text { Philippines } & \text { U.S.A. } \\ \text { Botswana } & \text { Ghana } & \text { Korea } & \text { Portugal } & \text { Uganda } \\ \text { Brazil } & \text { Greece } & \text { Lesotho } & \text { Rwanda } & \text { United Kingdom } \\ \text { Cameroon } & \text { Guatemala } & \text { Liberia } & \text { Senegal } & \text { Uruguay } \\ \text { Canada } & \text { Haiti } & \text { Malawi } & \text { Singapore } & \text { Venezuela } \\ \text { Central African Rep. } & \text { Honduras } & \text { Malaysia } & \text { South Africa } & \text { Yugoslavia } \\ \text { Chile } & \text { Hong Kong } & \text { Mexico } & \text { Spain } & \text { Zaire } \\ \text { Colombia } & \text { India } & \text { Nepal } & \text { Sri Lanka } & \text { Zambia } \\ \text { Congo } & \text { Indonesia } & \text { Netherlands } & \text { Sweden } & \text { Zimbabwe } \\ \text { Costa Rica } & \text { Iran } & \text { New Zealand } & \text { Switzerland } & \end{array}$




\section{Number of countries data: Definitions}

In most cases the determination of when a country appeared or disappeared is fairly uncontroversial. For example it is clear that the first German unification happened in 1871, that Algeria was born in 1962, and so on. In a number of cases, however, it may be unclear whether a country was independent or not. For instance, Afghanistan was under British 'influence' for some time, but never became a crown colony. For such cases, we had to use decision rules to determine the number of countries in any single year. These rules are the following:

1. For most of the countries, the dates of colonization and independence are specified in Encyclopedia Britannica, so we used those dates. We also double checked with Centennia, a computerized map program, whenever the data in Centennia was available. If conflicts occurred, we consulted country specific history books.

2. For a few countries, the process of colonization and gaining independence took a long time. We used the year in which a country lost control over its foreign policies as the starting point of colonization and the year that a country "fully" gained its independence as the year that it became independent. The word "fully" is usual terminology in the Encyclopedia Britannica and implies that the colonizer has left all powers to the local government.

3. If formal colonization did not occur for a given country, e.g. Bhutan, we used the criterion that its foreign policies was controlled by a foreign power as the starting point of colonization.

4. Countries that were under suzerainty of another country, e.g. Serbia and Romania under the Ottoman Empire, were classified as colonies.

5. A few countries, e.g. Afghanistan, were not colonized but were under the influence of foreign countries. They were classified as independent countries. 


\section{Data Sources and Description}

Variable Name: Growth

Source: Summers-Heston v. 5.6. Unit: \% points

Definition: Growth rate of PPP adjusted Gross Domestic Product

Variable Name: Trade/GDP Ratio

Source: Summers-Heston v. 5.6. Unit: \%

Definition: Ratio of imports plus exports to GDP.

Variable Name: Initial Income per capita

Source: Summers-Heston v. 5.6. Unit: Log of per capita GDP in Dollars Definition: Real Gross Domestic Product per capita in a given year (PPP adjusted)

Variable Name: Human Capital (male and female)

Source: Barro-Lee. Unit: Years

Definition: Avg. years of secondary and higher education in the total population over age 25.

Variable Name: Black Market Premium

Source: World Currency Yearbook and IMF. Unit: (Black market rateofficial rate)/official rate.

Definition: Black market premium on the exchange rate.

Variable Name: Public Consumption

Source: Summers-Heston v. 5. Units: \%

Definition: Share of government consumption of goods and services in GDP, excluding transfers and public investment.

Variable Name: Population

Source: Barro-Lee Unit: Logarithm of population.

Definition: Country population

Variable Name: Terms of Trade Shocks

Source: World Bank Unit: \%

Definition: Growth rate of merchandise export prices minus growth rate of merchandise import prices. 
Variable Name: Log of area

Source: Barro-Lee Unit: $\log$ of million of square kilometers.

Definition: Log of country land area

Variable Name: Landlocked dummy, Island dummy, Small country dummy.

Source: Authors. Unit: dummy variables

Definition: geographic dummy variables. 


\section{References}

Ades Alberto, and Edward Glaeser (1994), Evidence on Growth, Increasing Returns and the Extent of the Market, NBER Working Paper No. 4714.

Alesina, Alberto, and Enrico Spolaore (1997), On the Number and Size of Nations, forthcoming, Quarterly Journal of Economics.

_-_ (1996), International Conflict, Defense Spending and the Size of Countries, NBER Working Paper No. 5694, August.

Alesina, Alberto and Romain Wacziarg (1997), Openness, Country Size and the Government, NBER Working Paper No. 6024, May.

Barro, Robert and Xavier Sala-i-Martin (1995), Economic Growth, New York: McGraw Hill.

Bolton, Patrick, Gerard Roland and Enrico Spolaore (1996), Theories of the Breakup and Integration of Countries, European Economic Review, April.

Breuilly, J. (1996), The Formation of the First German Nation State, 1800-1871, St Martin Press, New York, NY.

Brubaker, R. (1990), Nationalism Reframed, Cambridge University Press, Cambridge, UK.

Bugajski, J. (1993), Nations in Turmoil, Westview Press, San Francisco.

Bulmer-Thomas, V. (1994), The Economic History of Latin America Since Independence, Cambridge University Press, Cambridge, UK.

Casella, Alessandra and J. Feinstein (1990), Public Goods in Trade: On the Formation of Markets and Political Jurisdictions, NBER Working Paper No. 3554, December.

De Melo, Jaime and Arvind Panagariya, eds. (1993), New Dimensions in Regional Integration, Cambridge University Press, Cambridge.

Drèze, Jean (1993), Regions of Europe: A Feasible Status, To Be Discussed, Economic Policy, 17.

Frankel, Jeffrey A. and David Romer (1995), Trade and Growth: An Empirical Investigation, mimeo, UC Berkeley, November.

Frenkel, Jacob, ed. (1997), The Regionalization of the World Economy, Cicago University Press, Chicago. 
Gallant, Ronald and Dale Jorgenson (1979), Statistical Inference for a System of Simultaneous. Non-linear, Implicit Equations in the Context of Instrumental Variable Estimation, Journal of Econometrics, 11, p. 275-302.

Grossman, Gene M.and Elhanan Helpman (1994), Protection for Sale, American Economic Review; vol. 84, no.4, September, p. 833-50.

Helliwell, John (1996), Do National Borders Matter for Québec's Trade?, unpublished.

Hobsbawm, Eric (1994), The Age of Extremes, Vintage Books, New York, NY. (1987), The Age of Empire, Vintage Books, New York, NY. (1990): Nations and Nationalism Since 1870, Cambridge University Press, Cambridge, UK.

Keynes, John Maynard (1920), The Economic Consequences of the Peace, Harcourt, Brace and Howe, New York.

Krugman, Paul (1991a), Is Bilateralisme Bad?, in E. Helpman and A. Razin (eds.), International Trade and Trade Policy, MIT Press, Cambridge, MA.

(1991b), The Move to Free Trade Zones, Federal Reserve Bank of Kansas City Review, December.

Mansori, Kashif S. (1996), Interregional Trade: Effects on the Build-up and Breakdown of Nations, unpublished, Princeton University, November.

Mathews, J. (1997), The Age of Non-State Actors, Foreign Affairs, January/February. pp. 50-66.

McCallum, J. (1995), National Borders Matter: Canada-US Regional Trade Patterns, American Economic Review, June, 615-23.

Michalopoulos, C and D. Torr (1992), Trade and Payments Arrangements for States of the Former USSR, World Bank Working Paper.

Newhouse, Joseph (1997), Europe's Rising Regionalism, Foreign Affairs, January/February, 67-84.

Nordhaus, William D., Merton J. Peck and Thomas J. Richardson (1991), Do Borders Matter? Soviet Economic Reform after the Coup, Brookings Papers on Economic Activity, vol. 2. 
Parry, J. H. (1990), The Spanish Seaborne Empire, University of California Press, Berkeley, CA.

Rodrik, Dani (1996), Why Do More Open Economies Have Bigger Governments?, NBER Working Paper no, 5537, April.

Sachs, Jeffrey and Andrew Warner (1995), Economic Reform and the Process of Global Integration, Brookings Papers on Economic Activity, no.1, p. $1-118$.

Spolaore, Enrico (1995), Economic Integration, Political Borders and Productivity, prepared for the CEPR-Sapir conference on "Regional Integration and Economic Growth", Tel Aviv University, December.

-__- (1997), Borders and Barriers, mimeo.

Tilly C. (1975), The Formation of National States in Western Europe, Princeton University Press, Princeton, NJ.

Van Selm, B. (1997), The Economics of Soviet Break-Up, Rutledge, London.

Viner, Jacob (1950), The Customs Union Issue, Carnegie Endowment for International Peace, New York.

Wacziarg, Romain (1990), La Naissance de l'Impérialisme Américain, Fondements et Facteurs, 1870-1917, unpublished thesis, Paris: Institut d'Etudes Politiques de Paris.

(1997), Measuring the Dynamic Gains from Trade, mimeo, Harvard University and World Bank, February.

Williamson, E. (1992), The Penguin History of Latin America, Penguin Books, London UK.

Wittman, D. (1991), Nations and States: Mergers and Acquisitions; Dissolution and Divorce, American Economic Review, Papers and Proceedings, May, 126-129. 


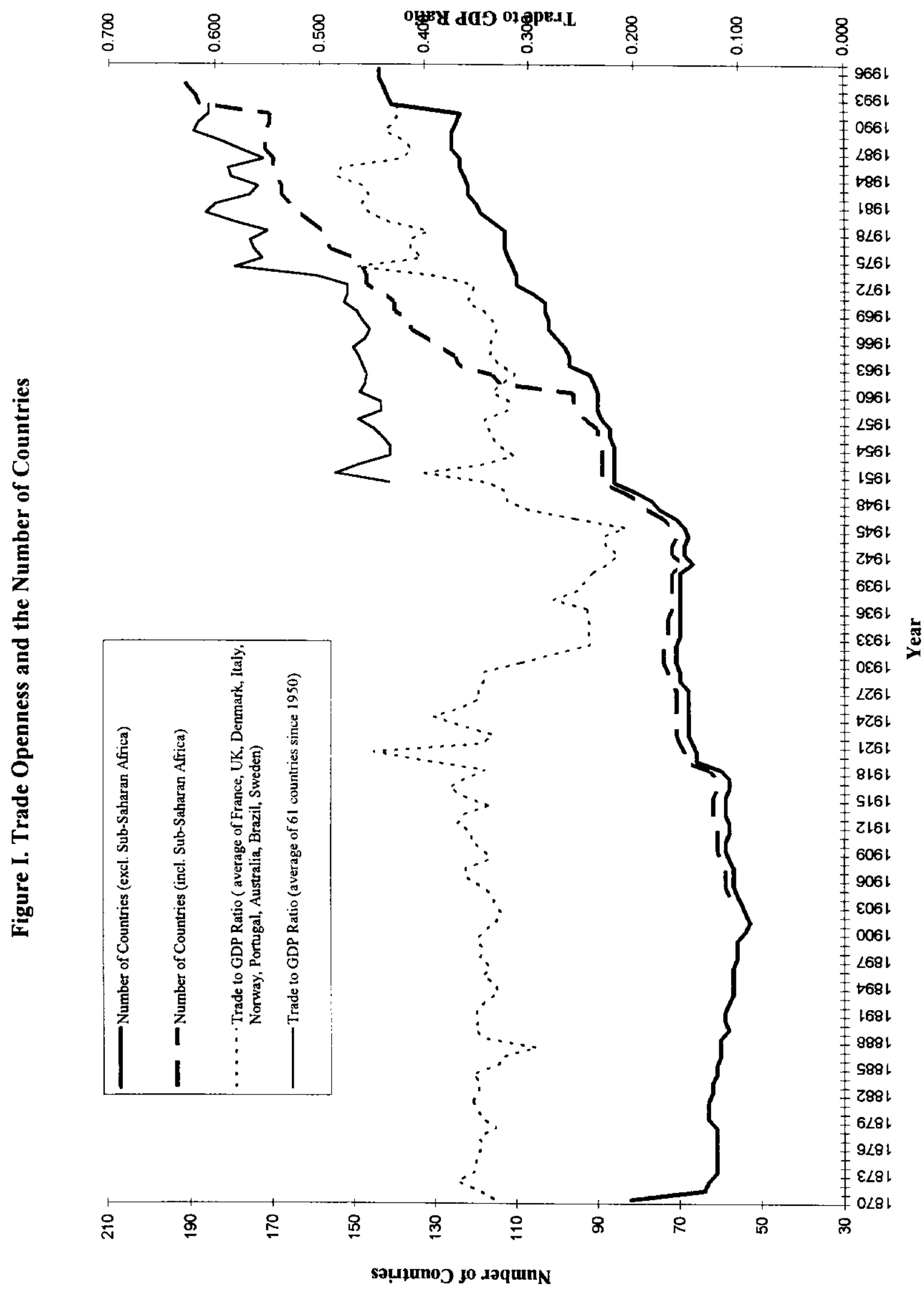




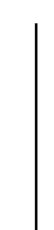




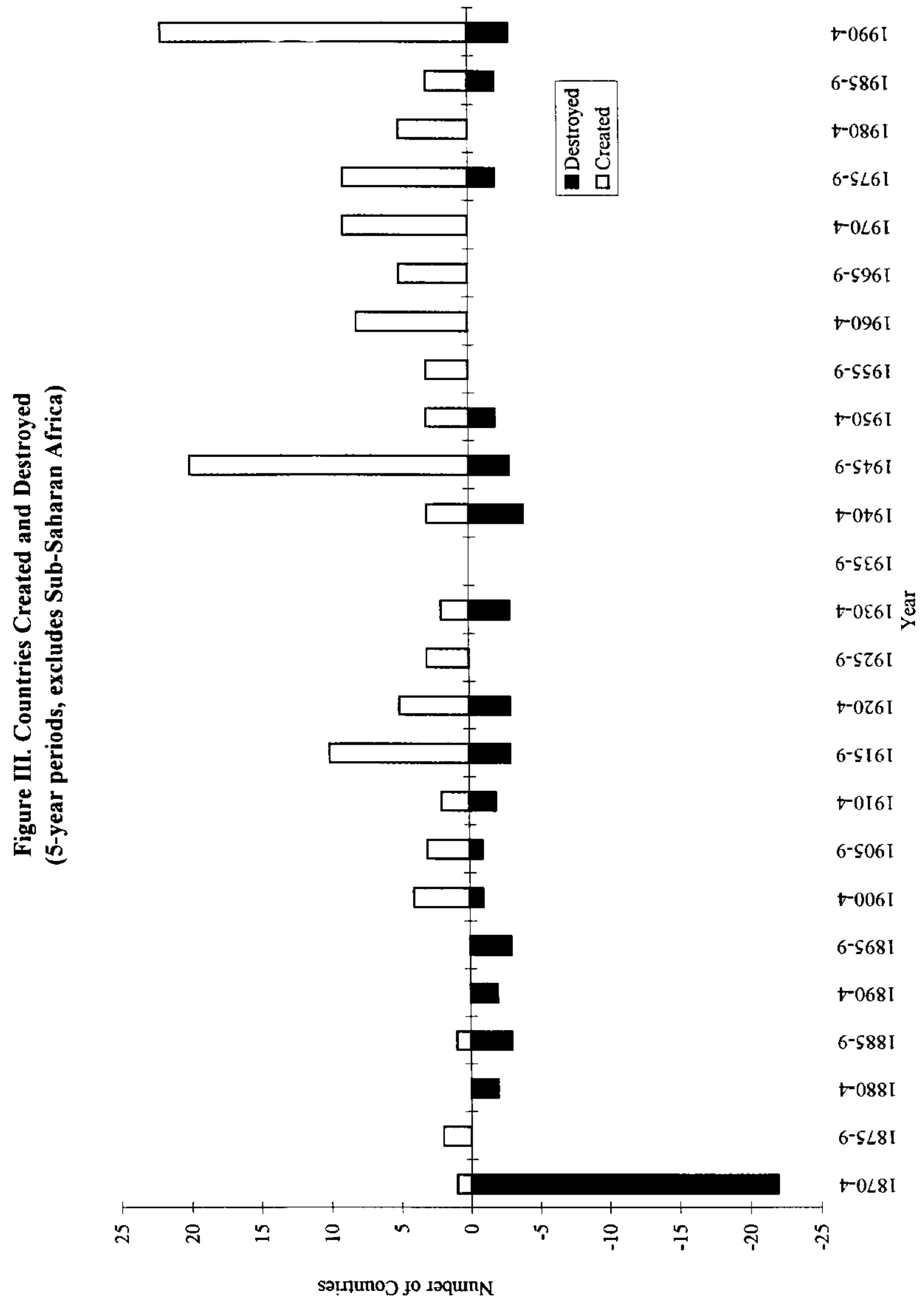




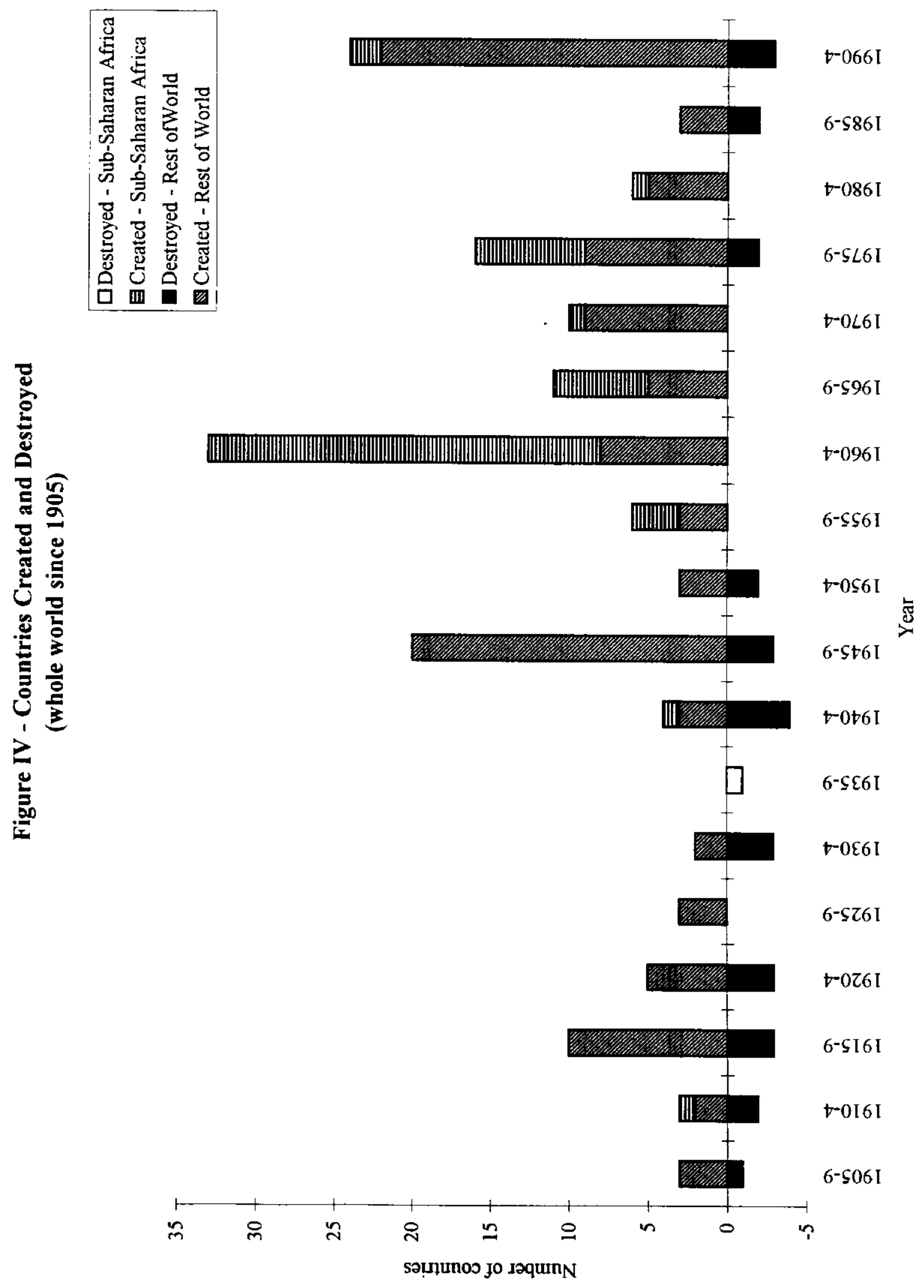

